\title{
Design of an aquaponic system run on solar power for a family business in Chad
}

\author{
Dolores Tous-Zamora ${ }^{a}$, Francisco de la Rosa-Sánchez ${ }^{a}$, Eva M. Sánchez-Teba ${ }^{\mathrm{a}^{*}}$, Manuel \\ Cordero-Tous $^{b}$, Rubén Ruiz-Campos ${ }^{c}$ \\ a Departamento de Economía y Administración de Empresas. Universidad de Málaga (Spain) \\ b Investigador Instituto Universitario de Domótica y Eficiencia Energética. Universidad de Málaga (Spain) \\ ${ }^{\mathrm{C}}$ Grupo de Investigación de Recursos Naturales. Universidad de Málaga (Spain)
}

Received 02 february 2019; accepted 11 June 2019

JEL

CLASSIFICATION

M10, M14

KEYWORDS

aquaponics;

aquaculture;

hydroponics;

integrated system;

solar power;

Chad

CÓDIGOS JEL

M10, M14

PALABRAS CLAVE

Acuoponía;

acuicultura;

hidroponía; sistema

integrado;

alimentación solar;

Chad

\begin{abstract}
This article describes the design of a single-family aquaponic system powered by solar energy. This technique called "aquaponi cs" is an activity that blends aquaculture (farming aquatic species) and hydroponics (growing plants in a water-based environment) into one integrated system. A description is given of the elements in the aquaponic circuit, which is sized to scale for a family business, in addition to the budget required for its implementation in Chad. The use of renewable energy offers the possibility of implementing sustainable farming in underdeveloped countries. The objective of this system is to maximize the production of fish and vegetables, taking into account their limitations ( $20 \mathrm{~kg}$ of fish can be produced for every 1,000 liters of water while 8 liters of water are necessary to grow each plant). The fish farmed in this case will be tilapia, as it is technically feasible and has a flavor that is acceptable to the inhabitants of Chad. The cultivated plants include all types of fruits and vegetables, as well as aromatic plants.
\end{abstract}

Diseño para una empresa familiar de un sistema acuapónico con energía solar en el Chad

Resumen Este artículo expondrá el diseño de un sistema acuapónico unifamiliar alimentado con energía solar. Esta técnica llamada "acuaponía", es una actividad en la que convergen la acuicultura (cría de especies acuáticas) y la hidroponía (cultivo de plantas sobre el agua) en un mismo sistema integrado. Se hace una descripción de los elementos del circuito acuapónico, un dimensionamiento a nivel de empresa familiar así como el presupuesto que permita su implementación en el Chad. Al incluir el uso de energías renovables, nos da la posibilidad de implementar el cultivo sostenible en países subdesarrollados. El objetivo de esta instalación es maximizar la producción de pescados y vegetales, teniendo en cuenta sus limitaciones (se pueden producir $20 \mathrm{~kg}$ de peces por cada 1000 litros de agua y son necesarios 8 litros por planta cultivada). El pescado que se criará será la tilapia, ya que técnicamente es factible y su sabor es aceptado por los habitantes del Chad. En cuando al cultivo de plantas, serán todo tipo de frutas y verduras, así como plantas aromáticas. 


\section{Introduction}

The environmental challenges facing the world have evolved over the past few decades as the population continues to grow, creating an onslaught of problems; it is therefore becoming increasingly important to develop new techniques for harvesting resources to feed humans in a sustainable way.

This article explains the design of a single-family aquaponic system powered with solar energy that is still not very widely used in Spain. This technique called "aquaponics" blends aquaculture (farming aquatic species) and hydroponics (growing plants in a water-based environment) into one integrated system.

Aquaculture products (generally fish) are permanently or periodically linked to hydroponic cultivation (vegetables) through a single water circuit. In this system, the metabolic waste generated by the fish and the leftover food are used by the plants and transformed into organic plant material (Somerville, C. 2014).

A valuable product is thereby generated by means of a disposable sub-product, with the added advantage of the water (free of nutrients) being available for reuse by fish and other aquatic species. This is what we call the solar aquaponics cycle, since the entire system functions with solar energy. Based on these reasons, aquaponics meets the criteria of environmental, social and economic sustainability (López. 2016).

This article explains the design of a single-family aquaponic system powered with solar energy that is still not used very extensively in Spain. This technique called "aquaponics" is an activity that blends aquaculture (farming aquatic species) and hydroponics (growing plants in a water-based environment) into one integrated system. This technology can boost the entrepreneurship of family businesses in third world countries (Carney, 2005), (Bañegil, Barroso y Tato, 2011)

The objective of this system is to maximize the production of fish and vegetables; however, there are limitations as 1,000 liters of water are needed for $20 \mathrm{~kg}$ of fish to live and grow, which means that 10,000 liters of water are required for this project ( 2 tanks of 2,000L and 6 tanks of $1,000 \mathrm{~L}$ ) for a total production of $200 \mathrm{~kg}$ of fish. For the hydroponic part of vegetable production, approximately 8 liters of water are needed for each plant, for a total of up to 1,200 plants.

\section{Antecedents}

This technique was already used in the Far East, Egypt, and in Aztec civilization. In regard to recent references, the first studies published on aquaponics are from the 1970s, which show that the metabolic waste produced by fish could be used as nutrients for cultivating plants using hydroponic methods (Wolfe, Zweig. 1977); (Lewis et al. 1978); (Naegel. 1977); (McLarney. 1972). But it wasn't until the 80s when aquaponic cultivation systems began to be used with closed circuits and sand filters; and the Speraneo system offered a major advance in separating the fish and plant areas (Bender. 1984); (Burgoon, Baum. 1984); (Rakocy. 1984), (1987), (1989); (Jensen, Collins, 1985) (Rennet, 1989) (Sanders, McMurty. 1988); (Zuckeman, et al. 1989). In the 90 s, concrete data applicable to commercial production began to be obtained (MCMutry.1993); (Clarkson, Lane. 1991) (Álvarez. 1999) (Masser. 1999) (Rakocy.1993), (1997); (Thomas. 1998); (Clarkson. 1991); (Resh. 1995) (Costaa-Pierce. 1998); (Guterstam. 1996); (Hochheimer. 1998); (Losordo. 1999); (Rakocy. 1993). In the beginning, cultivation beds with different substrates were used, such as sand or gravel. Although these systems are still in use today, they are not usually applied on a commercial scale, and having been substituted by other more appropriate systems including "root floating" and "nutrient film" techniques (NFT) (Rakocy 2004)(2006); (Bijo. 2007); (Conolly. 2010); (Diver. 2006); (Ramírez. 2013); (Bañuelos. 2017).

At the present time, every continent has aquaponic experiences and systems, especially the United States, Australia, Canada, Barbados, Nicaragua, China, Bangladesh, Japan, and, more recently, Europe. A few initiatives exist in Spain, with great potential for development (Bakiu. 2014); (Boutwell, 2007); (Caló. 2011); (Duning 2012); (Gómez. 2015); (Intagri. 2017); (Candarle. 2015); (Iturbide. 2008); (Ramos. 2006); (Range. 2005); (Jchapell. 2008), (Nueno, 2011), (Hernández y Mancebo, 2016), (Barros, Hernangómez y Martín, 2017).

\section{Methodology}

First, a review was conducted of the existing literature.

This is an innovative production system, since there are only two real case studies in existence in Spain: one in Malaga (a small family facility) and another in Murcia (a large-scale facility, currently in the installation phase). In Europe, there is only one of these systems fully operational in Germany. Given the scarce implementation of this production system, it was necessary to consult with researchers who are experts in this field, specifically from Aula del Mar (Giacosa, Mazzoleni y Usai, 2018). 
Table 1 Temperatures and precipitation in Chad.

$\begin{array}{lcccccccccccc} & \text { January } & \text { February } & \text { March } & \text { April } & \text { May } & \text { June } & \text { July } & \text { August } & \text { Sept. } & \text { October } & \text { Nov. } & \text { Dec. } \\ \text { Avg. Temp. }\left({ }^{\circ} \mathrm{C}\right) & 25.3 & 27.6 & 30.8 & 31.4 & 29.5 & 27.3 & 25.9 & 25.6 & 25.8 & 27.2 & 27.2 & 25.7 \\ \text { Min. Temp. }\left({ }^{\circ} \mathrm{C}\right) & 16.5 & 18.7 & 22.9 & 24.7 & 23.7 & 22.2 & 21.6 & 21.4 & 21 & 21.3 & 18.6 & 16.4 \\ \text { Max. Temp. }\left({ }^{\circ} \mathrm{C}\right) & 34.2 & 36.6 & 38.8 & 38.1 & 35.4 & 32.5 & 30.3 & 29.8 & 30.6 & 33.2 & 35.9 & 35 \\ \text { Avg. Temp. }\left({ }^{\circ} \mathrm{F}\right) & 77.5 & 81.7 & 87.4 & 88.5 & 85.1 & 81.1 & 78.6 & 78.1 & 78.4 & 81.0 & 81.0 & 78.3 \\ \text { Min. Temp. }\left({ }^{\circ} \mathrm{F}\right) & 61.7 & 65.7 & 73.2 & 76.5 & 74.7 & 72.0 & 70.9 & 70.5 & 69.8 & 70.3 & 65.5 & 61.5 \\ \text { Max. Temp. }\left({ }^{(} \mathrm{F}\right) & 93.6 & 97.9 & 101.8 & 100.6 & 95.7 & 90.5 & 86.5 & 85.6 & 87.1 & 91.8 & 96.6 & 95.0 \\ \text { Precipitation }(\mathrm{mm}) & 0 & 0 & 5 & 32 & 86 & 136 & 216 & 270 & 195 & 45 & 1 & 0\end{array}$

Neither of the two facilities that are currently in operation in Spain use solar energy, which is what we propose in this paper.

\section{Location}

Chad is located in the center of the African continent, and is twice the size of Spain. It has approximately 12 million inhabitants, $80 \%$ of which live off what they cultivate/breed. This region could greatly benefit from the use of aquaponic crops grown with renewable energy, since the area has no electricity network and the conditions for cultivation are rather difficult. The city we have chosen is Kélo, located in the southwestern part of the country, specifically the area of Bayaka, home to more than 3,500 orphan children who face serious problems of survival.

A brief climate study of the area is necessary in order to install the circuit, which is shown below in the table of temperatures and precipitation:

The temperatures have an annual variation of approximately $6^{\circ} \mathrm{C}$, with an average of $31^{\circ} \mathrm{C}$, which is the ideal temperature for farming fish such as tilapia. Precipitation is essentially nonexistent during the winter months, but it rains a great deal from May to November, with a peak in August with tropical storms.

Based on a study of solar maps of the area, we have extracted two values that are necessary for the design of the photovoltaic circuit: global horizontal irradiance $(\mathrm{GHI})$, and direct normal irradiance (DNI). The following values are present for the study area considered in this article (north of Moundou): GHI: $2300 \mathrm{~kW} \mathrm{~h} / \mathrm{m}^{2}$; DNI: $1800 \mathrm{kWh} / \mathrm{m}^{2}$.

\section{Required water}

Potable water must comply with a minimum set of conditions. The table below indicates these required characteristics. The required amount will be the total capacity of the tanks plus $20 \%$ extra to fill the pipes, pump, filter, and for possible evaporation. The circuit will be connected at all times to a water intake to compensate for water losses.

Table 2 Required water conditions.

$\begin{array}{lll}\text { Parameters } & \text { Units } & \text { Water input } \\ \mathrm{pH} & - & 7-8.5 \\ \text { Alkalinity }(\mathrm{KH}) & \mathrm{ppm} & 660 \\ \text { Hardness }(\mathrm{GH}) & \mathrm{ppm} & 300 \\ \text { Ammonia } & \mathrm{Mg} / \mathrm{l} & <1 \\ \text { Nitrites } & \mathrm{Mg} / \mathrm{l} & <1 \\ \text { Nitrates } & \mathrm{Mg} / \mathrm{l} & 5-150 \\ \text { Transparency } & - & \text { Adequate } \\ \text { Temperature } & { }^{\circ} \mathrm{C} & 28-31 \\ \text { Dissolved oxygen } & \mathrm{Mg} / \mathrm{l} & >5\end{array}$

\section{Description of the required equipment}

Tanks

The aquaculture production will take place in the tanks. There are multiple types according to size, shape and material. For this project, we will use IBC (Intermediate Bulk Container) tanks with a maximum capacity of $3 \mathrm{~m}^{3}$. They are transportable, rigid or flexible, made of plastic or metal, and are the most affordable tank of this type. The top surface will be cut open so that the fish tanks will be uncovered in order to put the fish in and take them out. The pipes will be installed by drilling on the sides of the tank, avoiding dead zones in order for the water to circulate as much as possible.

Pipes

The pipes will be of various diameters, based on the part of the circuit where they are located. The material used for the pipes is polyethylene, which offers the following advantages: unaffected by soil movement, odorless and tasteless, insoluble, resistant to chemical agents, low friction factor, thermal insulation, durable, requires little to no maintenance, flexible, and lightweight. 
An average of 1,500 liters/hour will be required to recirculate the water from the tanks. The water speed will be $0.5 \mathrm{~m} / \mathrm{s}$ with a diameter of $0.0325 \mathrm{~m}$.

The speed must be greater for the $1,000 \mathrm{~L}$ in the hydroponic part, used for drip irrigation of 39 vertical tubes with 30 plants per tube, since the load losses in the valves for drip irrigation are greater. The optimal speed in this part of the circuit is $0.8 \mathrm{~m} / \mathrm{s}$, with a diameter of $0.02099 \mathrm{~m}$. The collecting pipes of the tanks, which receive the discharge of the $32 \mathrm{~m}$ pipes, are associated with 4,000 liters in tanks, and therefore must have the capacity to evacuate 4,000 liters/hour. For the hydroponic part of vegetable production, the relationship has been estimated at $8 \mathrm{~L}$ per plant, allowing for the cultivation of up to 1,200 plants. The speed of evacuation will be less, fixed at $0.3 \mathrm{~m} / \mathrm{s}$. The diameters of the other pipes in the circuit are as follows:

Table 3 diameters of the other pipes in the circuit .

\begin{tabular}{|c|c|c|c|c|}
\hline Section & $\begin{array}{l}\text { Q in } \\
\text { circulation } \\
(\mathrm{l} / \mathrm{h})\end{array}$ & $\begin{array}{l}\mathrm{V}(\mathrm{s} \\
\mathrm{m} / \mathrm{s} \\
)\end{array}$ & $\begin{array}{l}\mathrm{DN} \\
(\mathrm{mm} \\
)\end{array}$ & $\begin{array}{l}\text { Normali } \\
\text { zed DN }\end{array}$ \\
\hline $\begin{array}{l}\text { Propulsion pumps- } \\
\text { distribution }\end{array}$ & 4,000 & 0.5 & 73.3 & 75 \\
\hline Distribution-tanks & 1,500 & 0.5 & $\begin{array}{l}0.03 \\
25\end{array}$ & 32 \\
\hline $\begin{array}{l}\text { Tank outlets- } \\
\text { manifold }\end{array}$ & 1,500 & 0.3 & $\begin{array}{c}0.04 \\
2\end{array}$ & 50 \\
\hline Main manifold-tank & 4,000 & 0.3 & $\begin{array}{c}0.06 \\
86\end{array}$ & 75 \\
\hline $\begin{array}{c}\text { Manifold } \\
\text { hydroponics }\end{array}$ & 1,000 & 0.8 & $\begin{array}{c}20.0 \\
5\end{array}$ & 20 \\
\hline $\begin{array}{l}\text { Propulsion pumps- } \\
\text { hydroponics area }\end{array}$ & 1,000 & - & 75 & 75 \\
\hline $\begin{array}{c}\text { Propulsion } \\
\text { hydroponics-main } \\
\text { tank }\end{array}$ & 1,000 & 0.8 & $\begin{array}{c}20.0 \\
5\end{array}$ & 20 \\
\hline $\begin{array}{l}\text { Propulsion pump- } \\
\text { filter }\end{array}$ & 500 & $\begin{array}{c}0.1 \\
5\end{array}$ & $\begin{array}{c}0.03 \\
34\end{array}$ & 32 \\
\hline $\begin{array}{l}\text { Propulsion pump-UV } \\
\text { filter }\end{array}$ & 1,500 & 0.5 & $\begin{array}{l}0.03 \\
25\end{array}$ & 32 \\
\hline
\end{tabular}

In addition to water flows, it is necessary to comply with certain pressure values, which are shown in the table below:

Table 4 values of water.

$\begin{array}{ccc}\begin{array}{c}\text { Normalized } \\ \text { diameter PE }(\mathrm{mm})\end{array} & \begin{array}{c}\text { Normalized pressure } \\ \left(\mathrm{Kg} / \mathrm{cm}^{2}\right)\end{array} & \begin{array}{c}\text { Water volume } \\ \left(\mathrm{m}^{3} / \mathrm{h}\right)\end{array} \\ 20 & 2.5 & 0.4 \\ 25 & 2.5 & 0.6 \\ 32 & 4 & 1.8 \\ 40 & 4 & 3.5 \\ 50 & 4 & 5 \\ 63 & 4 & 8 \\ 75 & 4 & 15 \\ & 4 & 22\end{array}$

\section{Biological filter}

This filter controls the amount of nitrites and nutrients that circulate from the aquaculture production to the hydroponics. It is essential in order to produce the aquaponics phenomenon. For this study, we will create our own filters, layer by layer, which are even more effective and with a total cost that is 5 times less expensive. Also, as they are gravity-based filters, they are easier to manufacture and install.

The order of the filtering stages is as follows: The first layer is a perforated rectangular plastic box that distributes the water flow falling throughout the entire filter in the form of rain. The flow will be controlled using a shut-off valve. Next, the water passes through 2 layers of mesh, each $3 \mathrm{~cm}$ thick, in order to eliminate the larger sediment particles. Next, there is a layer of Perlon fiber (physical filter), which is a filtering material consisting of numerous tiny balls of synthetic fibers. Finally, there is a layer of arlita, a very lightweight expanded clay aggregate. In addition to acting as a filter, arlita also favors bacteria nesting, which is a necessary process in order for the aquaponic process to occur. Hence, the filter is complete.

The filter has 3 phases: mechanical, physical and chemical. The chemical part is the hydroponic area for plants. It works through gravity, and the water must reach this part at low speed, essentially as it would naturally fall, which is achieved through manual regulation of the shutoff valve connected to this part of the circuit, which must filter $500 \mathrm{l} / \mathrm{h}$ at low speed. The measurements of the initial boxes are $40 \times 20 \mathrm{~cm}$.

$3.5 \mathrm{~cm}$-wide holes will be made in the boxes in order for the water to fall through the filter to the subsequent phase in the form of rain.

Just below the previous distribution box, 2 rectangular polypropylene mesh layers, measuring $40 \times 20 \times 3$, will serve as the mechanical part of the filter. This phase eliminates the larger sediment particles.

Next is a layer of Perlon fiber (physical filter). This material consists of spheres of synthetic fibers, which are $0.5 \mathrm{~cm}$ in diameter. It is durable, resistant to wear and tear, inexpensive, and has high elasticity.

The last layer is made of arlita, a very lightweight expanded clay aggregate. This material is ideal as it has excellent filtering properties and favors the bacteria nesting process, which is necessary in order for the nitrification phenomenon to occur. During this process, which can take days, the nested bacteria help the oxidation of the ammonium, which is converted into nitrate, and eventually nitrite.

All of these phases are installed in the boxes as mentioned above.

Tous Zamora, D., de la Rosa Sánchez, F., Sánchez Teba, E. M., Cordero Tous, M.,., Ruiz Campos, R. (2019). Design of an aquaponic system run on solar power for a family business in Chad. European Journal of Family Business, 9(1), 39-48. 


\section{Vertical tubes}

This vertical aquaponic design requires 39 vertical PVC tubes, which are 2 meters long and have a diameter of $75 \mathrm{~mm}$ each. They are used to grow 36 plants per tube, with holes perforated every $10 \mathrm{~cm}$, installed on the 4 "sides" of each tube so that there are 9 plants per side. A small container will be installed in each hole, from the inside of the tube, containing the substrate where the plants will grow. The water from the fish tanks will go to the higher part of these tubes, falling along all of these internal containers. The harvested plants will grow towards the outside of the tube, pushing through the holes.

These tubes will be screwed into harvesting tubes that are larger in diameter, which bring the water to the hydroponic manifold chamber. The water with the nutrients collected from the plants is pumped from this chamber to the aquaculture tanks.

\section{Aerator}

An aerator will be installed in the main tank in order to maintain the levels of oxygen above 5 $\mathrm{mg} / \mathrm{l}$. Since the objective is mass production of fish, the selected aerator will have a capacity of $140 \mathrm{~L} / \mathrm{min}$ of air, $100 \mathrm{~W}, 240 \mathrm{~V}$, with a $20 \mathrm{~mm}$ tube incorporated in order to introduce air at a pressure of 0.42 bar.

\section{Ultraviolet filter}

1,500 liters per hour will pass through this filter, pumped by Pump 1 . The circuit has a total quantity of 12,000 liters of water, therefore requiring a $55 \mathrm{~W}$ filter to work with a system of 20,000L.

\section{Auxiliary elements}

These elements are shown in the table below:

Table 5 Auxiliary elements.

\begin{tabular}{|c|c|c|}
\hline Element & $\begin{array}{l}\text { Diameter } \\
(\mathrm{mm})\end{array}$ & $\begin{array}{c}\text { Measurement } \\
\text { (unit) }\end{array}$ \\
\hline \multirow{3}{*}{$\begin{array}{l}\text { Elbow fitting: female } \\
\text { PVC } 90^{\circ}\end{array}$} & 75 & 7 \\
\hline & 32 & 10 \\
\hline & 20 & 7 \\
\hline \multirow[t]{2}{*}{ T's: female PVC } & $75-32$ & 15 \\
\hline & 20 & 6 \\
\hline \multirow[t]{2}{*}{$\begin{array}{l}\text { Ball valves: body and } \\
\text { ball in PVC, EPDM } \\
\text { joints, Teflon stop } \\
\text { ring, PN10 }\end{array}$} & 75 & 6 \\
\hline & 32 & 20 \\
\hline
\end{tabular}

\section{Pumps}

Five pumps will be used in this case, four of which receive water from the main tank. The water volume from the secondary pump will be controlled with a gate valve.

The required pumps do not have high flows and are not very tall, which means that they must be very powerful. They are therefore feasibly powered with photovoltaic energy.

The theoretical water flow to be pumped is $24,000 \mathrm{l} / \mathrm{h}$, and the design of the pumping unit is as follows:

PUMP 1: H-01. Submersible pump with a capacity of $14,000 \mathrm{l} / \mathrm{h}, 7$ meters high, $120 \mathrm{~W}, 50 \mathrm{~Hz}, 230 \mathrm{~V}$. Measurements: $208 \times 138 \times 158 \mathrm{~mm}$ and weighing $3.7 \mathrm{~kg}$. It will feed four 1,000-liter tanks and the UV filter in two branches at the entrance to the main tank. This pump will be in continuous operation.

PUMP 2: H-02. Submersible pump with a capacity of $9,000 \mathrm{l} / \mathrm{h}, 8.5$ meters high, $140 \mathrm{~W}, 230 \mathrm{~V}$. It will feed two 2,000-liter tanks and the mechanical filter in two branches at the entrance to the main tank. This pump will be in continuous operation.

PUMP 3: H-03. Submersible pump with a capacity of $7,500 \mathrm{l} / \mathrm{h}, 7$ meters high, $80 \mathrm{~W}, 230 \mathrm{~V}$. It will feed two 1,000-liter tanks and one recirculation branch to the main tank. This pump will be in continuous operation.

PUMP 4: H-04. Submersible pump with a capacity of 2,000 l/h, 3 meters high, 55W, 230V. It will feed the hydroponic part of the circuit. This pump will be in continuous operation.

PUMP 5: H-05 Submersible pump with a capacity of 2,000 l/h, 3 meters high, 55W, 230V. It will be used to return the water coming out of the hydroponic part. This pump will be operated when the water from the collection chamber reaches a certain level, which will be controlled with a buoy.

The load losses in the circuit are as follows:

Table 6 Load in the circuit.

$\begin{array}{cc}\text { Type of singularity } & \mathrm{K} \\ \text { Fully open valve } & 0.2 \\ \text { Half-open valve } & 5.6 \\ 90^{\circ} \text { Elbow } & 1 \\ 45^{\circ} \text { Elbow } & 0.4 \\ \text { Pipe outlet } & 1\end{array}$

The most unfavorable case is when there is increased speed, and when the constant has a value of 1 (pipe outlet or $90^{\circ}$ elbow). One of these areas is in the elbow fitting at the outlet of the propulsion of the hydroponic part, where the load loss is $0.0326 \mathrm{~m}$.

Tous Zamora, D., de la Rosa Sánchez, F., Sánchez Teba, E. M., Cordero Tous, M.,., Ruiz Campos, R. (2019). Design of an aquaponic system run on solar power for a family business in Chad. European Journal of Family Business, 9(1), 39-48. 
As the pumps have a minimum pumping height of 3 meters, these losses represent $1 \%$ of the total height; considering that there is not a long stretch of pipe to flow through, the load losses in the circuit are concluded to be negligible.

\section{Photovoltaic circuit}

The power supply for the mechanical equipment will be installed in a photovoltaic energy circuit, which functions as follows: the sun hits the photovoltaic panels, which creates a potential difference in the silicon crystal, which generates a continuous current that passes through the regulator, which then determines how much current is necessary for our consumption, and how much can be directed to the accumulation or battery system, thereby avoiding excessive charges/discharges. All of the consumption elements for this project use $220 \mathrm{~V}$ with an alternating current, therefore making it necessary to install an adaptation system for currents or inverters, which must have the capacity to support the full power of the system, taking into account the simultaneity coefficient for all uses of the circuit. This electronic circuit transforms the continuous current into an alternating current, and also changes the voltage required for said consumptions.

In order to calculate this circuit, the following steps are necessary:

Determination of the total power consumed by the system.

The consumption of active power must be defined and the simultaneity coefficient must be applied, based on the number of hours per day that the equipment will be in operation.

Table 7 Power consumption.

$\begin{array}{llll}\text { Element } & \begin{array}{l}\text { Voltage } \\ (\mathrm{W})\end{array} & \text { Coefficient } & \text { Total } \\ \text { Pump 1 } & 120 & 1 & 120 \\ \text { Pump 2 } & 140 & 1 & 140 \\ \text { Pump 3 } & 80 & 1 & 80 \\ \text { Pump 4 } & 55 & 1 & 55 \\ \text { Pump 5 } & 55 & 0.7 & 38.5 \\ \text { Aerator } & 100 & 1 & 100 \\ \text { UV Filter } & 55 & 1 & 55 \\ \text { LED lights } & 4 \times 30 & 0.5 & 60 \\ \text { Auxiliary } & 3600 & 0.1 & 360 \\ \text { electrical outlet } & & & 1,008.5 \\ \text { Total } & & & \end{array}$

The total required potential is multiplied by $24 \mathrm{~h}$, obtaining the consumption in Wh per day, which is $2.4204 \mathrm{Wh} /$ day. This type of installation has a yield of $75 \%$, making it necessary to use oversized equipment, which means that the total energy required is $32.272 \mathrm{Wh} /$ day.

Estimated local solar radiation.

The program PVGIS is used to obtain this figure, which requires the following inputs:

Latitude: $32^{\circ} 30$ " $" \mathrm{~N}$

Longitude: $3^{\circ} 41^{\prime} 29^{\prime \prime} \mathrm{E}$

Nominal potential of the Photovoltaic System:

$1 \mathrm{kWp}$

Slope of the modules: $35 \mathrm{deg}$.

Orientation (azimuth) of the modules: 0 deg.

Resulting in the following table:

Table 8 Radiation in Chad.

$\begin{array}{lllll}\text { Month } & \text { Ed } & \mathrm{Em} & \mathrm{Hd} & \mathrm{Hm} \\ \text { January } & 4.32 & 134 & 5.56 & 172 \\ \text { February } & 4.92 & 138 & 6.37 & 178 \\ \text { March } & 5.48 & 170 & 7.36 & 228 \\ \text { April } & 5.07 & 152 & 6.98 & 209 \\ \text { May } & 4.86 & 151 & 6.81 & 211 \\ \text { June } & 4.81 & 144 & 6.86 & 206 \\ \text { July } & 4.77 & 148 & 6.95 & 215 \\ \text { August } & 4.81 & 149 & 6.97 & 216 \\ \text { September } & 4.57 & 137 & 6.48 & 195 \\ \text { October } & 4.67 & 145 & 6.39 & 198 \\ \text { November } & 4.51 & 135 & 5.92 & 178 \\ \text { December } & 4.14 & 128 & 5.27 & 163 \\ & 4.74 & 144 & 6.49 & 197\end{array}$

Where:

Ed: Average daily electrical energy production of the system $(\mathrm{kWh})$

Em: Average monthly electrical energy

production of the system $(\mathrm{kWh})$

Hd: Daily average amount of overall irradiation

by square meter received by the modules of the system $\left(\mathrm{kWh} / \mathrm{m}^{2}\right)$

$\mathrm{Hm}$ : Monthly average amount of overall

irradiation by square meter received by the

modules of the system $\left(\mathrm{kWh} / \mathrm{m}^{2}\right)$

The month with the least amount of radiation (lowest $\mathrm{Hd}$ ) is December, with $5.27 \mathrm{kWh} / \mathrm{m}^{2}$, and therefore the system will be sized for this amount of radiation in order to ensure that the system will cover the demand for power in the circuit throughout the entire year.

A voltage of $1 \mathrm{~kW} / \mathrm{m}^{2}$ is used to calibrate the modules. The radiation obtained is then divided by this value, and the value of peak hours of sunshine (HSP) are required, which are 5.27 HSP. This figure represents the number of hours of sunshine equivalent to the sun shining with a voltage of $1,000 \mathrm{~W} / \mathrm{m}^{2}$, since the intensity of the

Tous Zamora, D., de la Rosa Sánchez, F., Sánchez Teba, E. M., Cordero Tous, M.,., Ruiz Campos, R. (2019). Design of an aquaponic system run on solar power for a family business in Chad. European Journal of Family Business, 9(1), 39-48. 
sun's radiation varies throughout the different hours of the day.

Calculation of the number of photovoltaic modules.

Polycrystalline photovoltaic panels are used, which are installed in the ground, minimizing the cost of installation.

It is very important to understand how variations in temperature can effect the electrical voltage and the current. Small variations in temperature can cause a great variation in intensity, while the voltage will continue to be practically constant. Since there are considerable variations in temperature in Chad, it is important to keep this in mind when selecting the appropriate panel.

To calculate the number of modules required, it is necessary to estimate the yield for the modules due to the orientation, dirt in the environment, installation, etc. This value varies from 0.7 to 0.8 . It is also necessary to know the peak power value of the modules to be installed. This value varies from 180 to $250 \mathrm{Wp}$. By selecting the lowest yield and the average peak power, the number of modules required is obtained: 44 200W modules for power supply in the least favorable month.

The voltage will be determined by the batteries that must be connected to the panels to store the energy collected during the day in order to work at night and recirculate the water at night. The SV 260 Poly model photovoltaic panel was selected as it fits the required profile.

The basic parameters for the design of the rest of this circuit are:

Intensity of short circuit (Isc): $8.94^{\mathrm{a}}$

Open circuit voltage (Voc): $34.8 \mathrm{~V}$

Maximum power $(\mathrm{Pm})$ : it can supply a maximum of $194.4 \mathrm{Wp}$ per module.

Maximum voltage $(\mathrm{Vm}): 28.5 \mathrm{~V}$.

Maximum current $(\mathrm{Im}): 6.76$ for the selected panel.

- Form factor (FF): The relationship between the maximum power (or the product of the current and the voltage at the point of maximum power) and the product of ISC and VOC. The better the cell, the higher the value.

- Efficiency: $15.51 \%$

The corners of the selected model are reinforced with ASA (a highly resistant hard plastic), which helps a lot in transportation as well as stability once it has been installed. The cells are connected in a series, surrounded by an EVA encapsulation (plastic), which seals the panel. It also has a Tedlar cover (another type of plastic), which makes the cells water tight, in addition to a glass cover.

Calculation of the capacity of the accumulation batteries.

In order to design the batteries' capacity, it is necessary to estimate the desired value of autonomy in order for the system to work on cloudy days or when there is little sunshine. The system will be in operation 7 days a week, 24 hours a day, and the estimated time without any sunshine is 6 days. Therefore, the capacity will be $13446.67 \mathrm{Ah}(\mathrm{c} 100)$. The depth of battery discharge is estimated at $60 \%$, and the voltage for each module will be $24 \mathrm{~V}$. C100 means that the calculation is valid for charging cycles of 100 hours, which is the value that is usually estimated for the electrification of isolated facilities. The charging and discharging periods should therefore be moderated, since the system will always be in operation.

The selection of the battery system is a critical point for the facility, since it is the part that usually breaks down in this type of photovoltaic systems. Replacement battery equipment must be on hand, since the shelf life of these batteries may be reduced due to low intensity charges or overloads.

The selected model is OPZS, with $2 \mathrm{~V}$ cells, specifically a Pc-Ac battery (lead acid) with liquid electrolyte. Since it has $2 \mathrm{~V}$ cells, it is necessary to form a battery bank of 12 units in order for the system to operate on 24V.

sine wave. As the total calculated power is $1,008 \mathrm{~W}$, the inverter must support this amount of power. The selected model is Ecosolar Blue 2,000W 24V.

Installation and start-up

We will need 2-3 weeks to install the system, with two workers working full-time.

The circuit must be installed indoors or under some type of greenhouse or roof, since the fish and plants will not survive in the desert climate of Chad if exposed to the elements.

These steps should be followed for start-up:

1. Fill the main tank, keeping the potable water supply always connected.

2. Check the photovoltaic electrical supply, and the configuration of the inverter.

3. Fill the aquaculture tanks by pumping. 4. Circulation of water through the hydroponic part by pumping. 
5. Circulation of water through the filter and the UV filter.

6. Turn on the aerator.

\section{Maintenance}

A worker is recommended to be on-site 24 hours a day since, if the circulation stops even for a few hours, it could have catastrophic consequences on the fish and plant population. The worker's tasks are as follows:

- Monitoring the water circulation through all of the parts of the circuit.

- Draining the tanks for cleaning.

- Unclogging the holes where water comes out.

- Harvesting fish, embyronated eggs and plants.

- Monitoring the fish population.

- Changing broken parts (valves, elbow fittings, Tee's...).

- Solving problems related to the photovoltaic system.

- $\quad$ Filling out the weekly control form.

\section{Overall system budget}

This is the price of the supply of the equipment used for the project. Approximately 15\% additional cost should be added for assembly. The price of the system will vary depending on the country where it is installed. With labor included, the budget may reach 10,000 euros.

\section{Conclusions}

The design of this system powered with solar energy is a viable solution for the problems of famine plaguing many underdeveloped countries. The sustainable cultivation of fish and plants responds to the population's needs of self-supply and is feasible in hostile environments for the development of conventional farmlands, especially in landlocked countries.

This paper is a proposal for action, describing the necessary elements for an aquaponic circuit

Table 9 Overall system budget.

Family aquaponics system budget

Item

1. Hydraulic circuit

1.1 Tanks

1,000L IBC Aquatic Tanks

2,000L IBC Aquatic Tanks

Total 1.1

1.2 Pipes

PE $100 \emptyset 75$ mm PN 16 distribution pipe

PE $100 \emptyset 50 \mathrm{~mm}$ PN 16 outlet collecting pipe

PE $100 \emptyset 32 \mathrm{~mm}$ PN 16 distribution and propulsion pipe UV filter

PE $100 \emptyset 20$ mm PN 16 exterior pipe hydroponic circuit

Total 1.2

1.3 Pumps

Submersible pump: $14,000 \mathrm{l} / \mathrm{h}, 7$ meters high, $120 \mathrm{~W}, 50 \mathrm{~Hz}, 230 \mathrm{~V}$ Grech model CTP-14000 or similar

Submersible pump: 9,000 l/h, 8.5 meters high, 140W, 230V Grech model CPP-16000F or similar

Submersible pump: 7,500 I/h, 7 meters high, $80 \mathrm{~W}, 230 \mathrm{~V}$ Grech model CPP-10000F or similar

Submersible pump: $2,000 \mathrm{l} / \mathrm{h}, 3$ meters high, 55W, 230V Sun Sun model HQB-2503 or similar

Total 1.3

1.4 Aquaponic filter

Plastic perforated box $40 \times 20 \mathrm{~cm}$ water distribution

Rectangular mesh filters PP $40 \times 20 \times 3 \mathrm{~cm}$

Physical filter: Perlon fiber layer $10 \mathrm{Kg}$

Arlita filter: bacteria nesting $10 \mathrm{Kg}$

Total 1.4

1.5 Hydroponic tubes

PVC Tubes $\emptyset 15 \mathrm{~cm} \times 2$ meters high for automation

Total 1.5

1.6 Hydraulic elements

Rensu LP-100 aerator or similar with capacity of $140 \mathrm{l} / \mathrm{min}$ of air, $100 \mathrm{~W}, 240 \mathrm{~V}$

Sun Sun UV Filter or similar CUV-155 55W, 240V

$90^{\circ}$ PVC female elbow fitting $\emptyset 75 \mathrm{~mm}$

$90^{\circ}$ PVC female elbow fitting $\emptyset 32 \mathrm{~mm}$

$90^{\circ}$ PVC female elbow fitting $\emptyset 20 \mathrm{~mm}$

PVC female Tee $\emptyset 75-32 \mathrm{~mm}$

PVC female Tee $\emptyset 20 \mathrm{~mm}$

Ball valves $\emptyset 32 \mathrm{~mm}$ body and ball in PVC, EPDM joints, Teflon stop ring, PN10

Ball valves $\varnothing 20 \mathrm{~mm}$ body and ball in PVC, EPDM joints, Teflon stop ring, PN11

Total 1.6

2. Photovoltaic circuit

Solar World photovoltaic panel or similar 60 x modules $260 \mathrm{Wp}, 24 \mathrm{~V} \mathrm{CC}$, Isc 8.94 A, Efficiency

$15.41 \%$

2 V Hoppecke battery cells 8 OPZS 800 or similar

Regulator with maximum power solar tracker, Bluesolar MPPT 75/15 A or similar

Ecosolar Blue Inverter 2000W 24V or similar with input 24V CC and output 230 V CA

Total 2

Total budget

$\begin{array}{llll}\text { Units } & \text { Measurement } & \text { Price } & \text { Total } \\ & & & \\ \text { unit } & 8 & 160 € & 1,280 € \\ \text { unit } & 2 & 200 € & 400 € \\ & & & 1,680 € \\ \mathrm{ml} & 40 & 8.77 € & 350.80 € \\ \mathrm{ml} & 10 & 3.96 € & 39.60 € \\ \mathrm{ml} & 60 & 1.67 € & 100.20 € \\ \mathrm{ml} & 35 & 0.70 € & 24.50 € \\ & & & \mathbf{5 1 5 . 1 0 €}\end{array}$

$\begin{array}{llll}\text { unit } & 1 & 83.47 € & 83.47 € \\ \text { unit } & 1 & 89.68 € & 89.68 € \\ \text { unit } & 2 & 88.20 € & 88.20 € \\ \text { unit } & 2 & 23.14 € & 46.28 € \\ & & & 307.63 €\end{array}$

unit $5 \quad 15 € \quad 75 €$

unit $2 \quad 10.50 € 21 €$

bag $1 \quad 2.59 € \quad 2.59 €$

$\begin{array}{lll}\text { bag } 1 & 6.25 € & 6.25 €\end{array}$

$6.25 €$
$104.84 €$

unit $40 \quad 11.40 € \quad 456 €$

$456 €$

unit $1 \quad 152 € \quad 152 €$

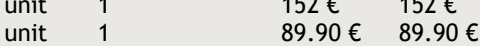

unit $7 \quad 7.80 € \quad 54.60 €$

unit $10 \quad 2.60 € \quad 26 €$

$\begin{array}{lll}\text { unit } 7 & 1.80 € & 12.60 €\end{array}$

unit $15 \quad 21.47 € \quad 322.05 €$

unit $6 \quad 7.50 € \quad 45 €$

$\begin{array}{llll}\text { unit } & 6 & 7.50 € & 45 € \\ \text { unit } & 25 & 5.97 € & 149.25 €\end{array}$

unit $6 \quad 3.50 € \quad 21 €$

$21 €$
$872.40 €$

unit $1 \quad 180 € \quad 180 €$

unit $12 \quad 335 € \quad 4,020 €$

unit $1 \quad 92.57 € 92.57 €$

$\begin{array}{lll}\text { unit } 1 & 32.57 € & 348 €\end{array}$

$4,640.57 €$

$8,576.54 €$

Tous Zamora, D., de la Rosa Sánchez, F., Sánchez Teba, E. M., Cordero Tous, M.,., Ruiz Campos, R. (2019). Design of an aquaponic system run on solar power for a family business in Chad. European Journal of Family Business, 9(1), 39-48. 
sized to scale for a family business, as well as the budget for its implementation in Chad.

It is necessary to ensure the electrical power supply for this system, as it is essential to preserve the production. The use of solar energy and an accumulation or battery system is therefore necessary for the system to operate on cloudy days or when there is little sunshine. The system will be in operation 7 days a week, 24 hours a day, with an estimate of periods without sunshine.

The maintenance of this type of system is vital since, if the circulation stops even for a few hours, it could have catastrophic consequences on the fish and plant population.

The production limitations are $20 \mathrm{Kg}$ of fish per 1,000 liters of water for the aquaponic part, and approximately 8 liters of water per plant for the hydroponic part of vegetable production. The cultivation of fish and vegetables must be planned taking these limitations into account.

\section{Bibliography}

Álvarez Torres, P. (1999). Desarrollo de la acuacultura en México y perspectivas de la acuacultura rural.

Bañeguil Palacios T.M, Barroso Martínez, A. y Tato Jiménez, J.L. (2011). Profesionalizarse, emprender y aliarse para que la empresa familiar continue. Revista de Empresa Familiar, 1(2), 2741.

Bañuelos Jaúregui, J.R. (2017). Acuaponía: parámetros básicos de diseño. Monografía. Torreón, Coahuila. Universidad Antonio Narro. México.

Bakiu, R., Shehu, J. (2014). Aquaponic system as excellent agricultural research instruments in Albania. Albanian Journal of Agricultural Sciences, 385.

Barros, I., Hernangómez, J. y Martín Cruz, N. (2017). Familiness and socioemotional wealth in Spanish family firms: An empirical examination. European Journal of family business. 7, 14-24.

Bender, J. (1984). An integrated system of aquaculture, vegetable production and solar heating in an urban environment. Aquacultural Engineering, III(2), 141-152.

Bijo, P. A., Thorarensen, H., Johannsson, R., Jensson, P. (2007). Feasibility study of a recirculation aquaculture system.

Boutwell, J. (2007). Aztecs aquaponics revamped. Napa Valley Register.

Burgoon, P.S., Baum, C. (1984). Year-round fish and vegetable production in a poassive solar greenhouse. Paper presented at the Sixth international congress on soilless culture, Lunteren, Holanda.

Caló, P. (2011). Introducción a la acuaponía. Centro Nacional de Desarrollo acuícola (CENADAC). Ministerio de Agricultura, Ganadería y Pesca. Argentina.
Candarle, P. (2015). Técnicas de acuponía, Centro Nacional de Desarrollo agrícola, (CENADAC), Dirección de acuicultura.

Carney, M. (2005). Corporate governance and competitive advantage in family-controlled firms. Entrepreneurship Theory and Practice, 29(3), 249-265.

Clarkson, R., Lane, S.D. (1991). Use of small-scale nutrient film hydroponic technique to reduce mineral accumulation in aquarium water. Aquaculture and fisheries management, XXII, 3745.

Connolly, K.T., T. (2010). Optimization of a backyard aquaponics. BREE 495, Design 3, Bioresource Engineering, Faculty of Agricultural and Environmental Sciences - McGill University.

Costa-Pierce, B.A. (1998). Preliminary investigation of an integrated aquaculture- wetland ecosystem using tertiary-treated municipal wastewater in Los Angeles Country, California.

Diver, S. (2006a). Aquaponics-Integration of hydroponics with aquaculture: Attra.

Diver, S. (2006b). Aquaponics-Integration of hydroponics with aquaculture: Attra - National Sustainable Agriculture Information Service.

Duning, R. D., Losordo, Thomas M and Hobbs, Alex O. (2012). A Spreadsheet Tool for the Economic Analysis of a Recirculation Tank System: Southern Regional Aquaculture Center.

Giacosa, E., Mazzoleni, A., \& Usai, A. (2018). Business Process Management (BPM) How complementary BPM capabilities can build an ambidextrous state in business process activities of family firms. Business Process Management Journal.

Gómez M., R.C., Ortega L., N.E., Trejo R., L.I. (2015). La acuoponía: Alternativa sustentable y potencial para producción de alimentos en México. Agroproductividad. 8(3), 60-65.

Guterstam, B. (1996). Demostrating ecological engineering for wasterwater treatment in a Nordic climate using aquaculture principles in a greenhouse mesocosm. Ecological Engineerign, VI, 73-97.

Hernández, F y Mancebo, E. (2016). Conditional mediation of competitive strategy and environment in international entrepreneurial orientation of family business. European Journal of family business. 6, 86-98.

Hochheimer, J.N. Wheaton, F. (1998). Biological filters: trickling and RBC design. Paper presented at the Proceedings of the Second International Conference on Recirculating Aquaculture, Roanoke, VA.

Iturbide D, K. (2008). Caracterización de los efluentes de dos sistemas de producción de tilapia y el posible uso de plantas como agentes de biorremediación. Universidad de San Carlos de Guatemala.

Jchapell, J. A; Brown, T. W y Purcell, T. (2008). A demonstration of tilapia and tomato cultureutilizing an energy efficient integrated system approach. 8th International Symposium o Tilapia in Aquaculture 2008. pp 23-32

Jensen, M.H., Collins, W.L., (1985). Hydroponic vegetable production. Hort. Rev. 7:483-558.

Tous Zamora, D., de la Rosa Sánchez, F., Sánchez Teba, E. M., Cordero Tous, M.,., Ruiz Campos, R. (2019). Design of an aquaponic system run on solar power for a family business in Chad. European Journal of Family Business, 9(1), 39-48. 
Lewis, V. M, Yopp, J.H, Scharamm, H.L, Brandenburg, A.M. (1978). Use of hydroponics to maintain.

López Jaime, J. (2016). Manual de Acuaponía, cultivo sostenible de peces y plantas. Málaga: Aula del Mar.

Losordo, T. (1999). Recirculating Aquaculture Tank Production System: A Review of Component Options: Southern Regional Aquaculture Center.

McLarney, W. (1972). Irrigation of garden vegetables with fertile fish pond water. New Alchemy Agricultural Research Report (2).

McMurtry, M.R, Sanders, D.C., Nelson, P. V. (1993). Mineral nutrient concentration and uptake by tomato irrigated with recirculating aquaculture water as influenced by quantity of fish waste products supplied. Journal of Plant Nutrition, XVI(3), 407-409.

McMurtry, M.R, Sanders, D.C, Cure, J.D, Hodson, R.G, Haning, B.C, St. Amand, P.C. (1997). Efficiency of water use of an integrated fish/vegetable co-culture system. J World Aquacult Soc 28:420-428.

Masser, M.P, Rakocy, J.E y Losordo, T.M. (1999). Recirculating aquaculture tank production systems: management of recirculating systems. Southern Regional Aquaculture Centre Publication No. 452. Southern Regional Aquaculture Centre, USA.

Naegel, L. C. A. (1977). Combined production of fish and plants in. Aquaculture, X(1), 17-24.

Nueno, P. (2011). Iniciativa emprendedora y empresa familiar: Emprendiendo a través de las generaciones. Universia Business Review, cuarto trimestre, 96-101.

Rakocy, J.E., (1984). A recirculating system for tilpia culture and vegetable hydroponics. In: R.C. Smitherman and D. Tave (Eds.), Proceedings of the Auburn Symposium on Fisheries and Aquiaculture, Auburn University, Auburn AL., pp.103-114.

Rakocy, J.E., Nair, A. (1987). Integrating fish culture and vegetable hydroponics: Problems and prospects. Virgin Islands Perspect, 19-23.

Rakocy, J.E. (1989). Hydroponic lettuce production in a recirculating fish culture system. Univ. Virgin Island Agric. Esp. Station, Island perspectives 3, 4-20.

Rakocy, J. E., Hargreaves, J.A., Bailey, D.S. (1989). Effects of hydroponic vegetable production on water quality in a closed recirculating system. J. World aquat. Soc., XX(1), 64A.

Rakocy, J.E., Hargreaves, J. A., Bailey, D.S. (1993). Nutrient accumulation in a recirculating aquaculture system integrated with vegetable hydroponic production. In: J.-K. Wang, Ed. Techniques for Modern Aquaculture. American Society of Agricultural Engineers, St. Joseph, MI, pp 148-158.

Rakocy, J.E., D.S. Bailey, K.A. Shultz and W.M. Cole. (1997). Evaluation of a commercial scale aquaponic unit for the production of tilapia and lettuce. Pages 357-372 in K. Fitzsimmons, ed. Tilapia Aquaculture: Proceedings of the Fourth International Symposium on Tilapia in Aquaculture, Orlando, Florida.
Rakocy, J.E, Shultz, R.C, Bailey, D.S. y Thoman, E.S. (2004). Aquaponic production of tilapia and basil: comparing a batch and staggered cropping system. Acta Horticulturae (ISHS) 648:63 69.47.

Rakocy, J.E, Masser, M.P y Losordo, T.M. (2006). Recirculating Aquaculture Tank Production Systems: Aquaponics-Integrating Fish and Plant Culture. Southern Regional Aquaculture Centre Publication No. 454. Southern Regional Aquaculture Centre, USA.

Ramirez Ballesteros, M. (2013). Evaluación del crecimiento de tilapia, acocil y lechuga en un Sistema de recirculación acuapónico en condiciones de laboratorio. Universidad Autónoma de México.

Ramos, C. (2006). Aquaponics Guadalajara. Aquaponics Journal., 40, 12-13

Range, P. Range B. (2005). Aquaponics helps to feed students, staff at orphanage in Reynosa, México. Aquaponics Journal., 39, 18-19.

Rennet, B (1989). The possibility of combined fish and vegetable production in greenhouse. Advanced Fish Science., 19-27.

Resh, H.M., (1995). Hydroponic food production: a definitive guidebook of soilless food-growing methods. Woodbridge Press Publishing Company, Santa Barbara, CA.

Sanders, D., McMurty, M.R. (1988). Fish increase greenhouse profits. American Vegetable Grower, 32-33.

Somerville, C.; Cohen, M.; Pantanella, E.; Stankus, A. \& Lovatelli, A. (2014). Small-scale Aquaponic Food Production. Integrated Fish and Plant Farming. FAO Fisheries and Aquaculture Technical Paper No. 589. Roma, FAO. 262 p.

Thomas M. Losordo, Michael P. Masser y James Rakocy. (1998). Recirculating Aquaculture Tank Production Systems: An Overview of Critical Considerations. Southern Regional Aquaculture Centre Publication No. 451. Southern Regional Aquaculture Centre, USA.

Wolfe, J., Zweig, R. (1977). Summary of fish culture techniques in solar aquatic ponds. Journal of the New Alchemist.

Zuckerman, B.M., M. Bess Dicklow, G.C.C., L Roberto (1989). Suppression of plant parasitic nematodes in the chinampa agricultural soils. Chemical Ecology, XV(6).

Tous Zamora, D., de la Rosa Sánchez, F., Sánchez Teba, E. M., Cordero Tous, M.,., Ruiz Campos, R. (2019). Design of an aquaponic system run on solar power for a family business in Chad. European Journal of Family Business, 9(1), 39-48. 